\title{
Heritability of myopia and its relation with GDJ2 and RASGRF1 genes in Lithuania
}

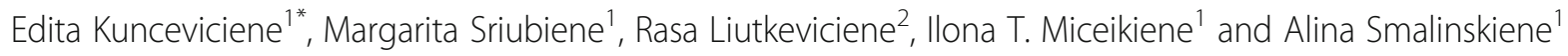

\begin{abstract}
Background: This study aimed to assess heritability of myopia in Lithuania and evaluate both genes GJD2 (Gap Junction Protein, Delta 2) and RASGRF1 (RAS protein-specific guanine nucleotide-releasing factor 1) relation with myopia.

Methods: In this study Lithuanian twin population aged between 18 and $40(n=460)$ were examined. Single-nucleotide polymorphisms of the RASGRF1 (rs8027411) and GJD2 (rs634990) genes were assessed by real-time polymerase chain reaction method.

Results: Intrapair correlations for spherical equivalent in all twin pairs were significantly higher in MZ twin pairs $r=0.539$ $(p<0.001,95 \% \mathrm{Cl} 0.353-0.684)$ than in DZ twin pairs $r=0.203(p<0.01,95 \% \mathrm{Cl} 0.0633-0.442)$ in myopia group. Correlations for spherical equivalent in emmetropia group were not significant in MZ twin pairs $r=0.091(p>0.05,95 \%$ $\mathrm{Cl}-0.215-0.381)$ and in DZ twin pairs $r=-0.220$ ( $p>0.05,95 \% \mathrm{Cl}-0.587-0.222)$. The odds ratio (95\% Cl) were 2.7 (1.018-7.460) for combinations of genotypes of rs634990 CC and rs8027411 GT ( $p=0.046)$.
\end{abstract}

Conclusions: Our studies have shown that the heritability of myopia makes $67.2 \%$ in Lithuania. Persons with combinations of genotypes rs634990 CC and rs8027411 GT have 2.7 times higher odds to have myopia.

Keywords: RASGRF1, GJD2, Twin, Myopia

\section{Background}

Refractive error is one of the priority targets of World Health Organization Vision 2020 [1]. More than 150 million people in the world are estimated to be visually impaired because of uncorrected refractive error, 8 million of them are functionally blind [2]. Myopia affects approximately one-third of adults older than 20 years in the United States, and in areas with high prevalence, specifically in urban East Asia, more than $80 \%$ of students graduating from school are myopic [3]. It is estimated that by the year 2020, 2.5 billion people - one third of the world's population will have been affected by myopia alone [4]. Worldwide, myopia affects approximately one in four individuals in western population and is the most common visual disorder $[4,5]$.

In Lithuania, the data on refractive errors are systematically collected, and the official statistics are published by the Lithuanian Department of Statistics. In the population of Lithuania from 2007 to 2014, the prevalence of

\footnotetext{
* Correspondence: edita.kunceviciene@lsmuni.lt

${ }^{1}$ Institute of Biology Systems and Genetic Research, Lithuanian University of

Health Sciences, 18 Tilzes St, Kaunas, Lithuania

Full list of author information is available at the end of the article
}

myopia increased from 44.3 to 63.9 per 1000 population (www.sic.hi.lt).

Both genetic and environmental factors can affect development of myopia, but the exact causes are not fully understood [6]. The genetic contribution to a trait often is assessed through heritability. Heritability is the proportion of phenotypic variability in a population trait that is due to genetic differences [7]. Up to now, the heritability of myopia has not been studied in Lithuania.

Twin studies allow us to estimate the overall gene influence, and the results can show the heritability of myopia. The twin method assumes that monozygotic (MZ) twins are influenced by largely similar environmental differences as dizygotic (DZ) twins, but MZ twins share the same genes whereas $\mathrm{DZ}$ twins on average share only half their genes [8]. Twin method is excellent for the estimation of heritability of myopia, but it does not show the specific genes that may possibly be involved in the heritability of myopia. Thus, we chose genetic markers, in order to establish whether any of them are significantly associated with myopia.

(c) The Author(s). 2018 Open Access This article is distributed under the terms of the Creative Commons Attribution 4.0 International License (http://creativecommons.org/licenses/by/4.0/), which permits unrestricted use, distribution, and reproduction in any medium, provided you give appropriate credit to the original author(s) and the source, provide a link to the Creative Commons license, and indicate if changes were made. The Creative Commons Public Domain Dedication waiver (http://creativecommons.org/publicdomain/zero/1.0/) applies to the data made available in this article, unless otherwise stated. 
Genome-wide association studies (GWAS) for refractive error showed that single nucleotide polymorphisms (SNPs) in $15 \mathrm{q} 25$ and $15 \mathrm{q} 14$ were associated with refractive error and myopia [9]. RASGFR1 is a gene made of 28 exons. This gene has a significant influence on development of myopia. RASGFR1 gene encodes Ras protein-specific guanine nucleotide-releasing factor-1, which is highly expressed in the retina and neurons. Then RASGFR1 gene proceeds to activate Ras [10, 11]. Also, RASGRF1 is a nuclear exchange factor that promotes GDP/GTP exchange on the Ras family GTPases and is related to synaptic transmission of the photoreceptor responses [12]. Muscarinic receptors and retinoic acid can regulate RASGRF1 expression as well [11]. Some animal and human studies showed that muscarinic inhibitors prevented the development of myopia [13]. In animal models of myopia there was detected reduced synthesis of choroidal retinoic acid [14]. To date, studies of SNP rs8027411 of RASGRF1 gene associations with high myopia in different populations have provided controversial results [6, 15-17].

The GJD2 gene at 15q14 encodes a neuron-specific protein connexin 36 (CX36), a $36 \mathrm{kDa}$ protein, which is a neuron-specific protein of a family of integral membrane proteins [18]. CX36 forms gap junction channels between adjacent membranes of neuronal cells. It is present in photoreceptors, bipolar and amacrine cells, and, by enabling intercellular transport of small molecules and ions, plays an essential role in the transmission process of the retinal electric circuitry $[18,19]$.

The aim of our research was to find associations between the GJD2, RASGRF1 genes and myopia
Table 1 Characteristics of twin pairs, defined by zygosity

\begin{tabular}{|c|c|c|c|}
\hline & MZ twins & DZ twins & $p$ value \\
\hline \multicolumn{4}{|l|}{ Sex, pairs } \\
\hline Male & 80 & 37 & $0.900^{\dagger}$ \\
\hline Female & 55 & 53 & \\
\hline Male/Female & & 5 & \\
\hline Total: & 135 & 95 & \\
\hline \multicolumn{4}{|l|}{ Age, years } \\
\hline Mean \pm SE & $24.10 \pm 0.54$ & $26.06 \pm 0.93$ & $0.379^{\ddagger}$ \\
\hline Median & 20.79 & 21.38 & \\
\hline Min, Max & 18,40 & 18,40 & \\
\hline \multicolumn{4}{|c|}{ Spherical equivalent (D) } \\
\hline $\mathrm{OD}$ Mean $\pm \mathrm{SE}$ & $-1.212 \pm 0.102$ & $-1.524 \pm 0.196$ & $0.667^{\ddagger}$ \\
\hline Median & -0.75 & -0.75 & \\
\hline Min, Max & $-7.25,0.375$ & $-7.375,0.49$ & \\
\hline OS Mean \pm SE & $-1.112 \pm 0.104$ & $-1.449 \pm 0.198$ & $0.338^{\ddagger}$ \\
\hline Median & -0.625 & -0.75 & \\
\hline Min, Max & $-7.25,0.35$ & $-6.75,0.49$ & \\
\hline
\end{tabular}

Abbreviations: $M Z$ - monozygotic twins; $D Z$ - dizygotic twins, $D$ diopters, $S E$ Standard error, $p>0.05$ - comparison between $M Z$ and $D Z$ twins

$\dagger p$ value for the chi-square test, $\neq p$ value for the Mann-Whitney test

development and to assess the heritability of myopia in Lithuania.

\section{Methods}

\section{Ethics statement}

Permission (Number P1-52/2005) to undertake the study was obtained from the Kaunas Regional Biomedical Research Ethics Committee. Before the study, the

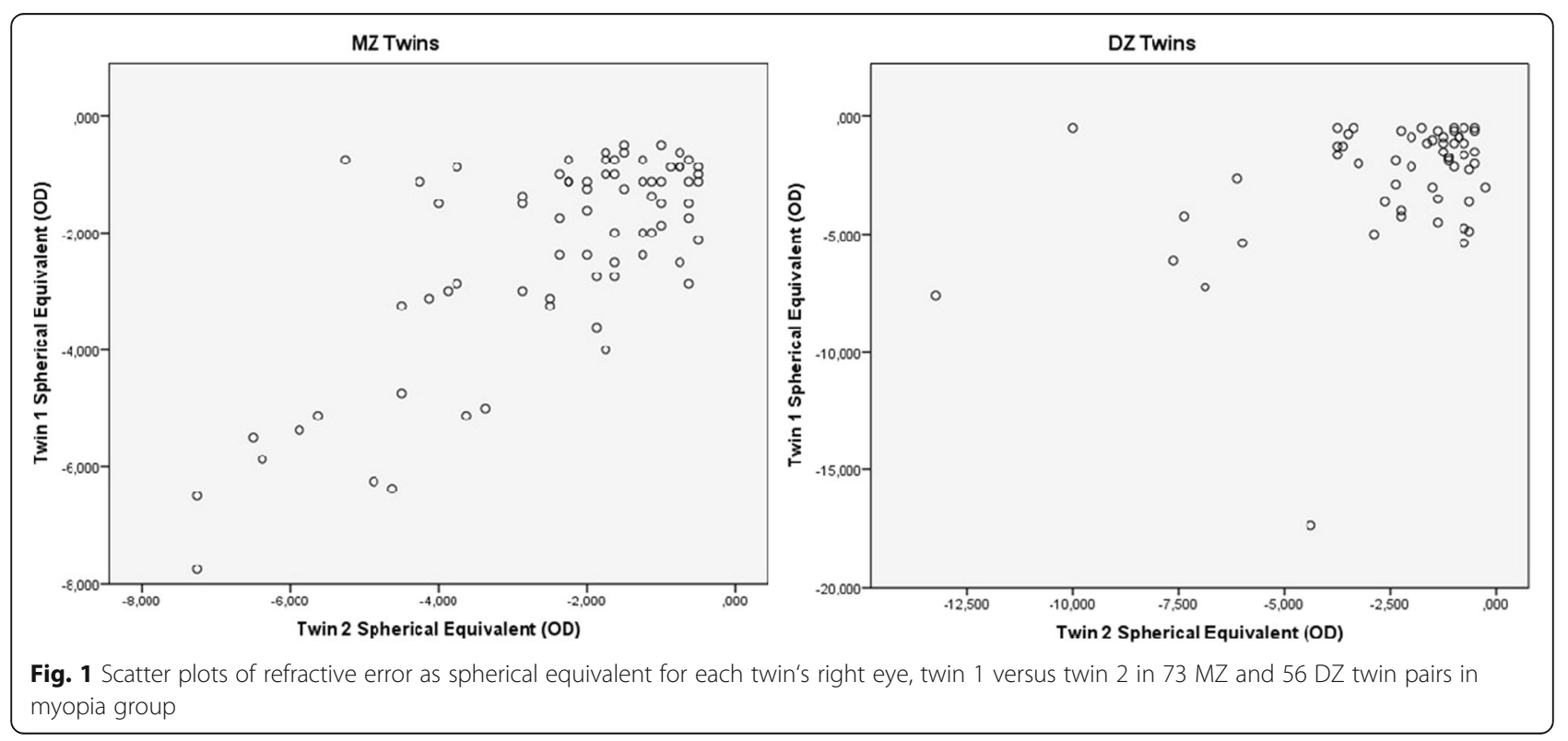




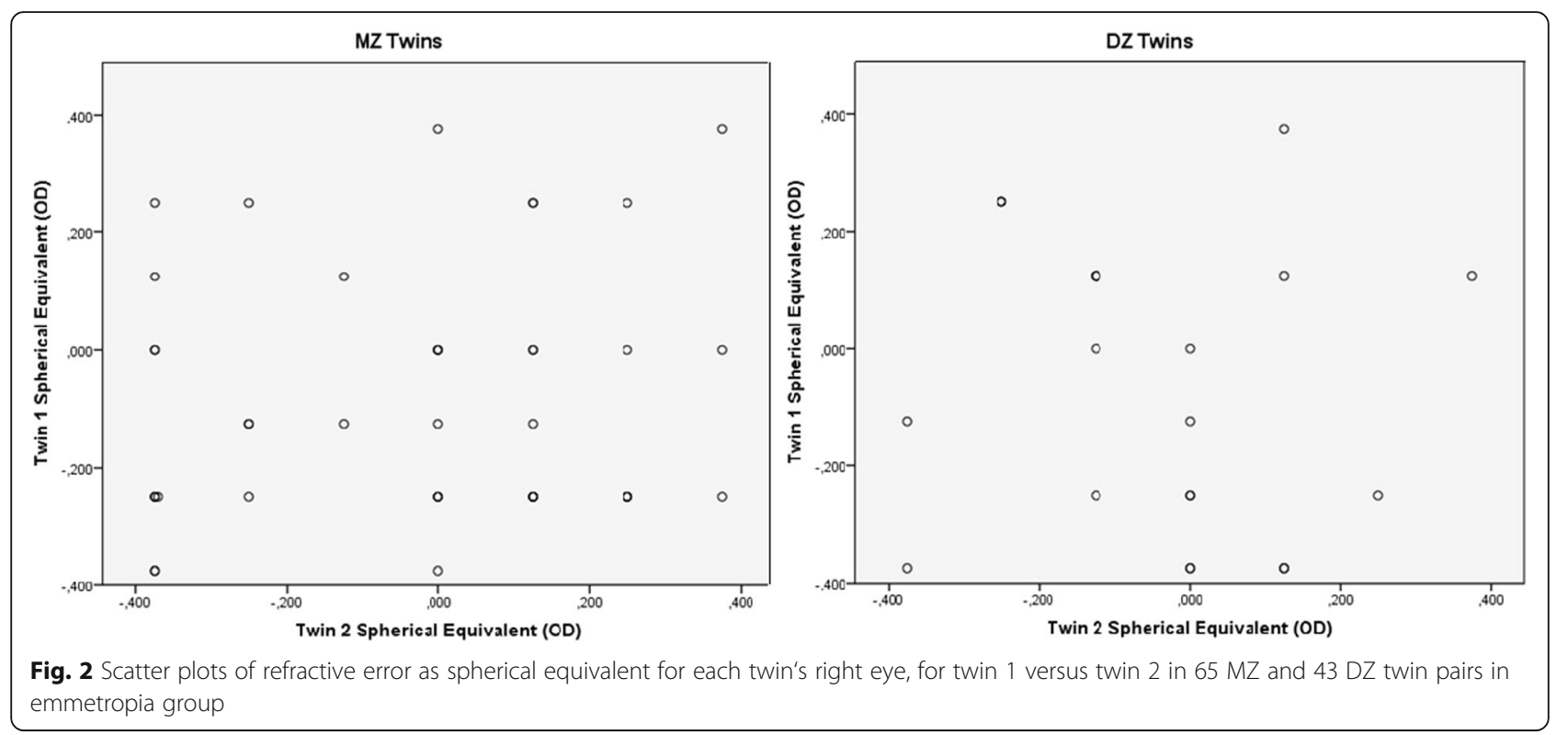

procedure and purpose of the study was explained, and an informed consent was obtained from all participants.

\section{Study samples}

The twins participating in this study were from the Twin Centre of Lithuanian University of Health Sciences. The Twin Centre has registered more than 600 twin pairs who agreed to participate in various medical and genetic studies. The study was conducted in the Institute of Biological Systems and Genetics Research, Lithuanian University of Health Sciences.

\section{Refractive error measurement}

Refractive error was measured with Sol. Cyclopentolate $1 \%$ using an autorefractor (Accuref-K9001, Shin-Nippon, Japan) and calculated by the mean spherical equivalent for each of the two eyes of every individual. The mean spherical equivalent was calculated using the standard formula: spherical equivalent $=$ sphere $+($ cylinder $/ 2)$.

$\mathrm{MZ}$ and $\mathrm{DZ}$ twins with spherical equivalent of at least one eye $>=-0.5 \mathrm{D}$ were assigned to the myopia group. Twins whose spherical equivalent was between 0.49 and $-0.49 \mathrm{D}$ were included in the emmetropia group. The myopia degree was determined by the strength or optical power of a corrective lens that focuses distant images on the retina: from $-0.5 \mathrm{D}$ to $-3 \mathrm{D}$ mild-degree myopia; from $-3 \mathrm{D}$ to $-6.0 \mathrm{D}$ medium-degree myopia; and -6.0 $\mathrm{D}$ and over high-degree myopia [20,21].

The exclusion criteria were as follows: 1) cataract, refractive surgery or other previous interventions that might have affected refractions; 2) other refractive errors; 3) refusal to participate in the research.

The inclusion criteria were as follows: 1) no ophthalmological eye disorders were found on detailed ophthalmological evaluation; 2) participation consent.

Lenses were evaluated by a slim-lamp biomicroscopy with the illumination source at a 45 degree angle and the light beam set being set to $2 \mathrm{~mm}$ width.

\section{Verification of zygosity}

Zygosity was determined using a DNA test. The polymerase chain reaction set (AmpFISTR ${ }^{\circ}$ Identifiler, Applied Biosystems, Foster City, CA, USA) was used to amplify short tandem repeats. 15 specific DNA markers were used for comparison of genetic profiles: D8S1179, D21S11, D7S820, CSF180, D3S1358, TH01, D13S317, D16S539, D2S1338, D19S433, vWA, TROX, D18S51, D5S818, and Amelogenin. The sample's gender, age, zygosity characteristics and spherical equivalents are shown in Table 1.

Table 2 Frequency of GJD2 and RASGRF1 genotypes and allele (\%)

\begin{tabular}{|c|c|c|c|c|c|c|c|}
\hline \multirow{2}{*}{$\frac{\text { SNP ID }}{\text { rs634990 }}$} & \multirow{2}{*}{$\frac{\text { Gene }}{\text { GJD2 }}$} & \multirow{2}{*}{$\frac{N}{272}$} & \multicolumn{3}{|c|}{ Genotype Frequency } & \multirow{2}{*}{$\begin{array}{l}\text { Minor allele frequency } \\
\text { C }\end{array}$} & \multirow{2}{*}{$\frac{P \text { value }}{0.1692}$} \\
\hline & & & CC & $\mathrm{CT}$ & $\pi$ & & \\
\hline & & & $56(20.6 \%)$ & 147 (54\%) & 69 (25.4\%) & $259(47.6 \%)$ & \\
\hline \multirow[t]{2}{*}{ rs8027411 } & RASGRF1 & 285 & GG & GT & $\pi$ & G & 0.0913 \\
\hline & & & 60 (21.1\%) & 157 (55.1\%) & 68 (23.8\%) & 277 (48.57\%) & \\
\hline
\end{tabular}


Table 3 Pooled results of the associations between GJD2 and myopia

\begin{tabular}{|c|c|c|c|c|c|}
\hline \multirow[b]{2}{*}{ Model } & \multirow[b]{2}{*}{ Genotype } & \multirow[b]{2}{*}{ Sig. } & \multirow[b]{2}{*}{$\operatorname{Exp}(B)$} & \multicolumn{2}{|c|}{ 95\% C.I. For $\operatorname{Exp}(B)$} \\
\hline & & & & Lower & Upper \\
\hline Codominant & $\begin{array}{l}\mathrm{CC} \\
\mathrm{CT} \\
\mathrm{TT}\end{array}$ & $\begin{array}{l}0.085 \\
0.742 \\
-\end{array}$ & $\begin{array}{l}2.000 \\
1.105 \\
-\end{array}$ & $\begin{array}{l}0.909 \\
0.611 \\
-\end{array}$ & $\begin{array}{l}4.401 \\
1.998 \\
-\end{array}$ \\
\hline Dominant & $(C C+C T)$ versus $\pi$ & 0.390 & 1.284 & 0.727 & 2.268 \\
\hline Recessive & $(C T+T T)$ versus $C C$ & 0.071 & 1.870 & 0.947 & 3.689 \\
\hline Overdominant & $(C C+T T)$ versus $C T$ & 0.467 & 0.828 & 0.499 & 1.376 \\
\hline Additive & - & 0.102 & 0.729 & 0.500 & 1.064 \\
\hline
\end{tabular}

\section{DNA extraction}

Peripheral blood samples were collected from each individual in ethylenediaminetetraacetic (EDTA) tubes for DNA extraction. DNA was extracted from leukocytes using a reagent kit (NucleoSpin Blood L Kit; Macherey \& Nagel, Düren, Germany). DNA samples from one member of each $\mathrm{MZ}$ pair were used for genotyping.

\section{Genotyping}

SNP of the GJD2 gene (rs634990) were assessed using a commercial genotyping kit C_2088259_10. SNP of the RASGRF1 gene (rs8027411) was assessed using a commercial genotyping kit C_185318_10 (Applied Biosystems, Foster City, CA, USA). The Applied Biosystems 7900HT Real-Time Polymerase Chain Reaction System was used for detecting the SNPs. The cycling program started with heating for $10 \mathrm{~min}$ at $95{ }^{\circ} \mathrm{C}$, followed by 40 cycles of $15 \mathrm{~s}$ at $95^{\circ} \mathrm{C}$ and $1 \mathrm{~min}$ at $60^{\circ}$ C. Allelic discrimination was carried out using the software of Applied Biosystems. Both SNPs (rs8027411, rs634990) were present in two previous GWASs.

\section{Statistical analysis}

The data was analysed with the statistical software package SPSS version 19.0 for Windows. Odds ratios and 95\% confidence intervals were computed to assess the association between two SNPs and myopia multivariate logistic

Table 4 Pooled results of the associations between RASGRF1 and myopia

\begin{tabular}{llllllll}
\hline & & & & & \multicolumn{2}{c}{ 95\% C.I. For Exp(B) } \\
\hline Model & Genotype & Sig. & Exp (B) & & Lower & Upper \\
\hline Codominant & $\mathrm{GG}$ & $\mathrm{GT}$ & 0.940 & 1.029 & & 0.488 & 2.173 \\
& $\mathrm{GT}$ & 0.680 & 0.880 & & 0.480 & 1.615 \\
& $\mathrm{TT}$ & - & - & - & - \\
Dominant & $(\mathrm{GG}+\mathrm{GT})$ versus $\mathrm{TT}$ & 0.774 & 0.918 & & 0.513 & 1.645 \\
Recessive & $(\mathrm{GT}+\mathrm{TT})$ versus GG & 0.705 & 1.126 & & 0.610 & 2.076 \\
Overdominant & $(\mathrm{GG}+\mathrm{TT})$ versus GT & 0.578 & 0.868 & & 0.528 & 1.428 \\
Additive & - & 0.096 & 0.991 & & 0.686 & 1.432 \\
\hline
\end{tabular}

Table 5 Odds ratio of myopia according to the combinations of GJD2 and RASGRF1

\begin{tabular}{|c|c|c|c|c|c|}
\hline \multicolumn{6}{|l|}{ Myopia } \\
\hline \multicolumn{4}{|l|}{ Genotype } & \multicolumn{2}{|c|}{$95 \%$ C.I. For $\operatorname{Exp}(B)$} \\
\hline $\begin{array}{l}\text { GJD2 } \\
\text { SNP ID rs634990 }\end{array}$ & $\begin{array}{l}\text { RASGRF1 } \\
\text { SNP ID rS8027411 }\end{array}$ & Sig. & $\operatorname{Exp}(B)$ & Lower & Upper \\
\hline CC & GG & 0.540 & 0.692 & 0.213 & 2.244 \\
\hline CC & GT & $0.046+$ & 2.756 & 1.018 & 7.460 \\
\hline CC & $\pi$ & 0.335 & 1.898 & 0.516 & 6.980 \\
\hline$C T$ & GG & 0.460 & 1.407 & 0.569 & 3.482 \\
\hline$C T$ & $\mathrm{GT}$ & 0.284 & 0.747 & 0.439 & 1.273 \\
\hline$C T$ & $\pi$ & 0.706 & 0.864 & 0.405 & 1.845 \\
\hline$\pi$ & GG & 0.990 & 1.006 & 0.391 & 2.587 \\
\hline$\Pi$ & GT & 0.129 & 0.542 & 0.246 & 1.195 \\
\hline$\pi$ & $\pi$ & 0.857 & 1.096 & 0.403 & 2.986 \\
\hline
\end{tabular}

$\dagger p<0.05$ comparison between myopia and emmetropia combinations of genotypes

regression (Tables 3). Statistical significance was determined at a two-tailed $p=0.05$ level. Estimate of heritability $\left(\mathrm{h}^{2}\right)$ was obtained Pearson's correlations ( $r$ ) for MZ and DZ twin pairs: $\mathrm{h}^{2}=2 \times\left(\mathrm{r}_{\mathrm{MZ}}-\mathrm{r}_{\mathrm{DZ}}\right)[22]$.

\section{Results}

230 pairs of twins (135 MZ and $95 \mathrm{DZ}$ ) aged between 18 and 40 participated in the study, their mean age being 25.08 years (SE 0.7 years) (Table 1 ). The mean spherical equivalent was $-1.324 \pm 0.150$, with a range from $0.49 \mathrm{D}$ to $-7.375 \mathrm{D}$. There were no significant differences between $\mathrm{MZ}$ and DZ twins in age and spherical equivalent of the left and right eyes.

Refractive errors for twin 1 versus twin 2 for mean of spherical equivalent are shown in figs. 1 and 2. Intrapair correlations for spherical equivalent in twin pairs were significantly higher in MZ twin pairs $r=0.539(p<0.001$, 95\% CI 0.353-0.684) than in DZ twin pairs $r=0.203$ $(p<0.01,95 \%$ CI $0.0633-0.442)$ in myopia group. Correlations for spherical equivalent in emmetropia group were not significant: $r=0.091(p>0.05,995 \%$ CI $-0.215-0.381)$ in $\mathrm{MZ}$ twin pairs and $r=-0.220$ ( $\mathrm{p}>0.05$, 95\% CI -0.587-0.222) in DZ twin pairs. The correlations of $\mathrm{MZ}$ were clearly higher compared to DZ pairs, indicating genetic effects on myopia.

We genotyped two SNPs (rs634990 and rs8027411) in 189 myopia (83 MZ and $106 \mathrm{DZ}$ ) and 96 emmetropia (25 MZ and $71 \mathrm{DZ}$ ) subjects. The results are shown in Table 2. The distribution of the two SNP genotypes matched the Hardy-Weinberg equilibrium $(p \geq 0.05)$. High-degree myopia was present in 11 cases, 33 twins had medium-degree 10 and 145 twins mild-degree myopia. But we didn't find significant correlations between myopia degree and genotypes. 
Table 6 Distribution of SNP rs634990 and SNP rs8027411 genotypes according to degrees of myopia

\begin{tabular}{|c|c|c|c|c|c|c|c|c|c|c|c|c|c|c|c|c|}
\hline \multirow[t]{2}{*}{$\begin{array}{l}\text { Myopia } \\
\text { degree }\end{array}$} & \multirow[t]{2}{*}{$\mathrm{N}$} & \multicolumn{3}{|c|}{$\begin{array}{l}\text { SNP ID rs634990 } \\
N=272\end{array}$} & \multicolumn{3}{|c|}{$\begin{array}{l}\text { SNP ID rs } 8027411 \\
N=285\end{array}$} & \multicolumn{9}{|c|}{ Combinations of genotypes: SNP ID rs634990 + SNP ID rs8027411 } \\
\hline & & $\overline{C C}$ & $\mathrm{CT}$ & $\pi$ & $\overline{\mathrm{GG}}$ & GT & $\pi$ & $\overline{C C+G G}$ & $\mathrm{CC}+\mathrm{GT}$ & $\mathrm{CC}+\mathrm{TT}$ & $\mathrm{CT}+\mathrm{GG}$ & $\mathrm{CT}+\mathrm{GT}$ & $C T+T$ & $T+\mathrm{GG}$ & $T+\mathrm{GT}$ & $\Pi+\Pi$ \\
\hline High & 11 & 4 & 5 & 2 & 3 & 6 & 2 & 1 & 2 & 1 & 2 & 2 & 1 & 0 & 2 & 0 \\
\hline Moderate & 33 & 7 & 20 & 6 & 8 & 17 & 8 & 2 & 4 & 1 & 4 & 10 & 5 & 2 & 4 & 0 \\
\hline Low & 145 & 32 & 80 & 20 & 34 & 83 & 28 & 8 & 18 & 6 & 18 & 50 & 12 & 9 & 10 & 1 \\
\hline Control & 96 & 13 & 42 & 41 & 15 & 51 & 30 & 1 & 8 & 4 & 8 & 27 & 7 & 6 & 16 & 19 \\
\hline
\end{tabular}

5 models were used to calculate the odds ratios to have myopia separately with each gene (GJD2 or RASGRF1), results were not significant (Table 3 , Table 4).

But we found significant association between the combinations of GJD2 CC and RASGRF1 GT and myopia (Table 5). The odds ratio of myopia compared to emmetropia (95\% confidence intervals [CIs]) was 2.7 (1.018-7.460) for GJD2 CC and RASGRF1 GT genotypes.

The number with combinations of genotypes rs634990 CC and rs8027411 GT and myopia degrees are shown in Table 6.

\section{Discussion}

We estimated heritability of myopia according to correlations for $\mathrm{MZ}$ and DZ twin pairs and our study showed $67.2 \%$ heritability of myopia. Three published twin studies of refractive error have found high heritability from 84 to $86 \%$ [23], 89 to $94 \%$ [24] and 75 to $88 \%$ [25]. It is indicate that heritability in Lithuania is lower than in other Europian populations. Dirani et al. have reported that different populations have shown a wide range of heritability estimates ranging from 50 to $90 \%$ [25]. Results shown that the samples of the population and different methods may affect the estimates of heritability [25]. In our study $77 \%$ twins had mild-degree myopia, $17 \%$ - medium-degree and 6\% - high-degree myopia. Meanwhile, the medium-degree myopia accounted for the largest portion in the mentioned studies of heritability in Europe.

Study showed that the gene GJD2, located nearest to the locus $15 \mathrm{q} 14$, and RASGRF1 15q25 are important for the transmission and processing of visual signals $[23,26]$. The studies of genetic associations in some European and Japanese populations showed that common genetic variations located in GJD2 and RASGRF1 were associated with common myopia and refractive error $[5,11,15]$.

A study of genome-wide associations (GWASs) showed associations of SNP with refractive error in 5328 individuals of the Dutch population which were not related. They found that carriers of the $\mathrm{C}$ allele of rs634990 have a higher risk of myopia [5]. Qiang et al. found that RASGRF1 gene was significantly associated with high-degree myopia (risk allele T) but GJD2 gene was not [15]. Also, results of meta-analysis, which included 2529 individuals with high-degree myopia and 3127 controls, showed that RASGRF1 was significantly associated with high-degree myopia in Chinese and Japanese populations. However, carriers of the RASGRF1 $G$ allele had a lower risk of high-degree myopia compared to carriers of the $T$ allele ( $G$ versus $T$ ) [27]. Also, Hysi et al. found that individuals carrying TT alleles on the RASGRF1 were significantly more likely to have myopia than those homozygous for the non-susceptibility GG alleles. We found a significant association between combinations of GJD2 and RASGRF1 genotypes and myopia. Our study showed that individuals with combinations of GJD2 CC and RASGRF1 GT genotypes were 2.7 times more likely to have myopia $(p=0.046)$. This indicates that some of our results are consistent with the previous reports. Individuals carrying $\mathrm{CC}$ alleles on the GJD2 were significantly more likely to have myopia than carriers of TT alleles. But carriers of GT allele on the RASGRF1 gene had more risk to have myopia than carriers of wild type alleles.

\section{Conclusion}

Our studies have shown that the heritability of myopia makes $66.4 \%$ in Lithuania. We detected significant associations between the combinations of GJD2 CC and RASGRF1 GT and odds ratio of developing myopia.

\section{Abbreviations}

D: Diopters; DZ: Dizygotic twins; GJD2: Gap Junction Protein Delta 2;

MZ: Monozygotic twins; RASGRF1: RAS protein-specific guanine nucleotide-releasing factor 1; SE: Standard error

\section{Acknowledgements}

We wish to thanks all the twins who agreed to participate in this study.

\section{Funding}

Funding for the research was obtained from the Lithuanian University of Health Sciences.

\section{Availability of data and materials}

The datasets during and/or analyzed during the current study available from the corresponding author on reasonable request.

Authors' contributions

$E K, R L, M S$ analyzed the data. EK, RL wrote the manuscript. EK, AS developed the structure for the paper. AS, RL, MS made critical revisions. EK, AS, ITM approved final version. All authors approved of the final manuscript. 


\section{Ethics approval and consent to participate}

Permission (Number P1-52/2005) to undertake the study was obtained from the Kaunas Regional Biomedical Research Ethics Committee. Participation in the study form is completed.

\section{Competing interests}

The authors declare that they have no competing interests.

\section{Publisher's Note}

Springer Nature remains neutral with regard to jurisdictional claims in published maps and institutional affiliations.

\section{Author details}

${ }^{1}$ Institute of Biology Systems and Genetic Research, Lithuanian University of Health Sciences, 18 Tilzes St, Kaunas, Lithuania. ${ }^{2}$ Department of Ophthalmology, Lithuanian University of Health Sciences, 2 Eiveniu St, Kaunas, Lithuania.

Received: 6 October 2016 Accepted: 10 May 2018

Published online: 24 May 2018

\section{References}

1. Dandona L, Dandona R. What is the global burden of visual impairment? BMC Med. 2006;:6.

2. Holden BA, Fricke TR, Ho SM, et al. Global vision impairment due to uncorrected presbyopia. Arch Ophthalmol. 2008;126:1731-9.

3. Lin LL, Shih YF, Hsiao CK, Chen CJ. Prevalence of myopia in Taiwanese schoolchildren: 1983 to 2000. Ann Acad Med Singap. 2004;33:27-33.

4. Kempen JH, Mitchell P, Lee KE, et al. The prevalence of refractive errors among adults in the United States, Western Europe, and Australia. Arch Ophthalmol. 2004;122:495-505.

5. Solouki AM, Verhoeven VJ, Duijn CM, et al. A genome-wide association study identifies a susceptibility locus for refractive errors and myopia at 15q14. Nat Genet. 2010:42:897-901.

6. Hayashi H, Yamashiro K, Nakanishi H, et al. Association of $15 q 14$ and $15 q 25$ with high myopia in Japanese. Invest Ophthalmol Vis Sci. 2011;52:4853-8.

7. Liew SH, Elsner H, Spector TD, Hammond CJ. The first "classical" twin study? Analysis of refractive error using monozygotic and dizygotic twins published in 1922. Twin Res Hum Genet. 2005;8:198-200.

8. Luft FC. Twins in cardiovascular genetic research. Hypertension. 2001;37(2): 350-6.

9. Nakanishi H, Yamada R, Gotoh N, et al. A genome-wide association analysis identified a novel susceptible locus for pathological myopia at 11q24.1. PLoS Genet; 2009. https://doi.org/10.137/journal.pgen.1000660.

10. Zippel R, Gnesutta N, Matus-Leibovitch N, et al. Ras-grf, the activator of ras, is expressed preferentially in mature neurons of the central nervous system. Brain Res Mol Brain Res. 1997:48:140-4.

11. Hysi PG, Young TL, Mackey DA. A genome-wide association study for myopia and refractive error identifies a susceptibility locus at 15q25. Nat Genet. 2010;42:902-5.

12. Shi $Y$, Gong B, Chen $L$, et al. A genome-wide meta-analysis identifies two novel loci associated with high myopia in the Han Chinese population. Hum Mol Genet. 2013;22:2325-33.

13. Tong L, Huang XL, Koh AL, Zhang X, Tan DT, Chua WH. Atropine for the treatment of childhood myopia: effect on myopia progression after cessation of atropine. Ophthalmology. 2009;116:572-9.

14. Mertz JR, Wallman J. Choroidal retinoic acid synthesis. A possible mediator between refractive error and compensatory eye growth. Exp Eye Res. 2000; 70:519-27.

15. Qiang Y, Li W, Wang Q, et al. Association study of $15 q 14$ and $15 q 25$ with high myopia in the Han Chinese population. BMC Genet. 2014;15:51.

16. Zhu JY, Rong WN, Jia Q, et al. Associations of single nucleotide polymorphisms of chromosomes $15 q 14,15 q 25$ and $13 q 12.12$ regions with high myopic eyes in hui and Han population of Chinese Ningxia area. Chin J Exp Ophthalmol. 2014;32:354-8.

17. Jiao X, Wang P, Li S, et al. Association of markers at chromosome $15 q 14$ in Chinese patients with moderate to high myopia. Mol Vis. 2012;18:2633-46.

18. Kihara AH, Paschon V, Cardoso CM, et al. Connexin36, an essential element in the rod pathway, is highly expressed in the essentially rodless retina of Gallus gallus. J Comp Neurol. 2009;512:651-63.
19. Striedinger K, Petrasch-Parwez E, Zoidl G, et al. Loss of connexin36 increases retinal cell vulnerability to secondary cell loss. Eur J Neurosci. 2005;22:605-16.

20. Young TL, Metlapally R, Shay AE. Complex trait genetics of refractive error. Arch Ophthalmol. 2007;125:38-48.

21. Fernández-Medarde A, et al. RasGRF1 disruption causes retinal photoreception defects and associated transcriptomic alterations. J Neurochem. 2009;110:641-52.

22. Neale MC, Cardon LR. Methodology for genetic studies of twins and families. NATO ASI series. Dordrech: Kluwer; 1992.

23. Hammond CJ, Snieder H, Gilbert CE, Spector TD. Genes and environment in refractive error: the twin eye study. Invest Ophthalmol Vis Sci. 2001;42: $1232-6$

24. Lyhne N, Sjolie AK, Kyvik KO, Green A. The importance of genes and environment for ocular refraction and its determiners: a population based study among 20-45 year old twins. Br J Ophthalmol. 2001;85:1470-6.

25. Dirani M, Chamberlain M, Shekar SN, et al. Heritability of refractive error and ocular biometrics: the genes in myopia (GEM) twin study. Invest Ophthalmol Vis Sci. 2006;47:4756-61.

26. Deans MR, Volgyi B, Goodenough DA, Bloomfield SA, Paul DL. Connexin36 is essential for transmission of rod-mediated visual signals in the mammalian retina. Neuron. 2002;36(4):703-12. https://doi.org/10.1016/ S0896-6273(02)01046-2.

27. Chen T, Shan G, Ma J, Zhong Y. Polymorphism in the RASGRF1 gene with high myopia: a meta-analysis. Mol Vis. 2015;21:1272-80.

\section{Ready to submit your research? Choose BMC and benefit from:}

- fast, convenient online submission

- thorough peer review by experienced researchers in your field

- rapid publication on acceptance

- support for research data, including large and complex data types

- gold Open Access which fosters wider collaboration and increased citations

- maximum visibility for your research: over $100 \mathrm{M}$ website views per year

At BMC, research is always in progress.

Learn more biomedcentral.com/submissions 